\title{
Artificial Aggregate Lightweight Structural
}

\author{
Subandi*, Robby Hadi Cahyono, Chandra Kusuma, Muhammad Noor Asnan \\ Universitas Muhammadiyah Kalimantan Timur, Jl.Ir.Juanda No.51, Samarinda, Kalimantan Timur 75124, Indonesia
}

Corresponding Author Email: 17111024430022@umkt.ac.id

https://doi.org/10.18280/acsm.430403

Received: 10 May 2019

Accepted: 19 July 2019

\section{Keywords:}

artificial ingredients 1, ironwood 2, lightweight 2, concrete 4, material 5

\begin{abstract}
The need for lightweight concrete in a variety of applications of modern construction technology is increasing rapidly, the weight and compressive strength of structural lightweight concrete is $1,850 \mathrm{~kg} / \mathrm{m}^{3}$, and the compressive strength of $17.2 \mathrm{MPa}$. Many methods are used to obtain lightweight concrete, including in this study conducting experiments to make structural lightweight concrete using iron wood waste, iron wood is made to replace rough aggregate by cutting iron wood into pieces and then coated with leakproof without dropping paint followed by sprinkling sand while the paint is still wet. From the test results the weight and compressive strength at 28 days, concrete weight $1772 \mathrm{~kg} /$ $\mathrm{m}^{3}$, and compressive strength 17.99 MPa. From the results of strong and compressive strength tests using iron wood waste as a substitute for coarse aggregate, concrete using iron wood aggregate meets the standards as structural lightweight concrete. That the use of iron wood waste as a substitute for coarse aggregate in the way that we make can be an alternative as a substitute for coarse aggregate for making structural lightweight concrete. This material in addition to being used as material for making structural lightweight concrete can also help reduce waste.
\end{abstract}

\section{INTRODUCTION}

Structural lightweight concrete according to the American Concrete Institute ACI is concrete weighing $1850 \mathrm{~kg} / \mathrm{m}^{3}$ and compressive strength of concrete at a minimum of $17.2 \mathrm{MPa}$ [1].

Concrete has been used since ancient times. Regular Roman concrete, for example, was made from volcanic ash (pozzolan), and hydrated lime. Roman concrete was superior to other concrete recipes (for example, those consisting of only sand and lime) used by other cultures. Besides volcanic ash for making regular Roman concrete, brick dust can also be used. Besides regular Roman concrete, the Romans also invented hydraulic concrete, which they made from volcanic ash and clay [2].

Lightweight aggregate concretes can be used for structural applications, with strengths equivalent to normal weight concrete.

The benefits of using lightweight aggregate concrete include, Reduction in dead loads making savings in foundations and reinforcement, Improved thermal properties., Improved fire resistance, Savings in transporting and handling precast units on-site, Reduction in formwork and propping.

The elastic modulus of lightweight concretes is lower than the equivalent strength normal weight concrete, but when considering the deflection of a slab or beam, this is counteracted by the reduced self-weight. The basic design for lightweight concrete is covered in Euro code 2 Part 1-1, with section 11 having particular rules required for lightweight aggregate concretes. Concrete is considered to be lightweight is the density is not more than $2200 \mathrm{~kg} / \mathrm{m}^{3}$ (the density of normal weight concrete is assumed to be between $2300 \mathrm{~kg} /$ $\mathrm{m}^{3}$ and $2400 \mathrm{~kg} / \mathrm{m}^{3}$ ) and a proportion of the aggregate should have a density of less than $2000 \mathrm{~kg} / \mathrm{m}^{3}$. Lightweight concrete can be specified using the notation LC for the strength class, e.g. LC30/33, which denotes a lightweight concrete with a cylinder strength of $30 \mathrm{MPa}$ and a cube strength of $33 \mathrm{MPa}$ [3].

Research using waste has been carried out for use in making concrete, including using rice husk charcoal as a substitute for fine aggregate and as an additive in making concrete $[4,5]$. some using red mud as a partial substitute for cement [6], Making lightweight concrete using coconut shell aggregate and sawdust jugat has also been carried out [7] The use of iron wood waste and rice husk charcoal has been examined from the results of this study, both materials are able to replace coarse and fine aggregates to produce lightweight structural concrete [8].

Ironwood is very widely used in East Kalimantan both as a wooden building material or as a substitute for reinforcing iron and to this day in areas that are still difficult to reach by six-wheeled vehicles still use ironwood as sticks, columns, beams, reinforcing bars and other iron- other.

Ironwood is a wood that is very commonly used as building material in East Kalimantan because ironwood is very strong and resistant to all weather along with expensive and long time to do housework with wood materials, causing wood to start to be replaced with concrete materials, of course this causes a lot of restoration office houses and others, causing more and more ironwood wood waste, apart from that the increasing demand for ironwood molding outside the area is increasing the waste from the wood, so far the waste has only been burned and discharged into the river so that it has the potential to create environmental pollution and air, it is, of course, the solution must be sought to reduce 
environmental pollution.

For this reason, we conducted a study to make lightweight concrete derived from ironwood waste as a substitute for a portion of coarse aggregate. The aim is to utilize waste and so that the weight of the concrete can meet the maximum weight of the lightweight concrete that has been set $1842 \mathrm{~kg} /$ $\mathrm{m}^{3}$.

No Drop is a leak-proof coating that has elastic, waterproof properties and is very weather resistant so it is suitable for use on wall surfaces, concrete, asbestos, galvanized / zinc and terracotta surfaces [9].

In this research we use ironwood waste as a substitute for coarse aggregate, making ironwood as a substitute for coarse aggregate will be discussed in the next chapter.

\section{MATERIAL AND METHOD}

\subsection{Ironwood aggregate manufacture}

The wood used, in this study as an aggregate is ironwood waste. Ironwood wood waste is cut into pieces and divided to a maximum of $20 \mathrm{~mm}$, then the results of the pieces are washed with water until clean, then no drop paint mixed with water with a ratio of 1: 2 then stirred until blended, after stirring evenly input the ironwood in the paint and stir until evenly let stand approximately 5 minutes, after that prepare dry sand, remove ironwood from paint and mix it until the surface of the ulin wood waste is covered with sand, put the ulin wood waste pieces that have been mixed evenly with sand in a flat place, and leave it for 12-24 hours before use. The process of making ironwood aggregates see Figures 1, and 2 .

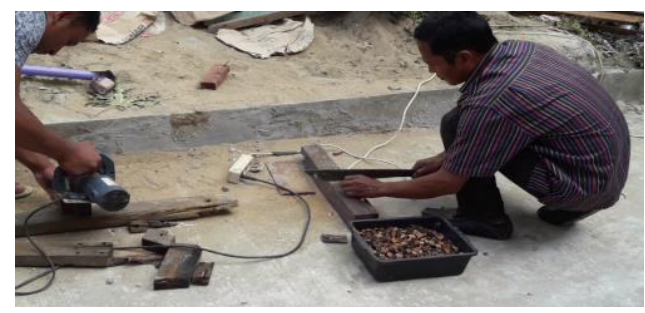

Figure 1. Cutting ironwood



Figure 2. Pieces of ironwood that have been given no drop paint and sand powder

\subsection{Material testing}

Material testing in this study uses the Indonesian national standard method and ASTM [10-15].

\subsection{Mix design}

Mix design in this study, using Indonesian National standards [16].

\subsection{Compressive strength}

The test object to be used is a cylindrical test object with a diameter of $15 \mathrm{~cm} \times 30 \mathrm{~cm}$, in accordance with Indonesian national standards [17].

\subsection{Slump test}

The planned slump test is $8 \mathrm{~cm}-18 \mathrm{~cm}$, the slump test uses an Abrams cone, and the method used is. An example of a mixture of fresh concrete is put into a mold that has a conical shape and is compacted with a piercing rod.

\subsubsection{Slump test procedure}

(1) Wet the mold and place it on a flat, moist surface, does not absorb water and is rigid. The mold must be held firmly in place during filling, by the operator standing on the stampede. From the concrete samples obtained according to Item 6 , immediately fill the mold in three layers, each layer approximately one-third of the volume of the mold.

(2) Solid each layer with 25 stitches using a compacting rod. Spread the stitching evenly over the surface of each layer. For the lower layer this will require a skewed incision and make approximately half of the number of punctures close to the edge of the mold, and then continue the vertical stabbing in a spiral around the center of the surface. Compact the entire layer down to its depth. Avoid puncturing sticks about the mold base plate. Compact the second layer and the top layer all the way to its depth, so that the puncture penetrates the boundary layer below.

(3) In filling and compacting the top layer, add the concrete mixture over the mold before compaction begins. If solidification results in concrete falling below the top end of the mold, add a concrete stir to keep the excess concrete at the top of the mold. After the top layer is compacted, flatten the concrete surface at the top of the mold by rolling the piercing rod over it.

(4) Remove the mold from the concrete immediately by carefully lifting it in the vertical direction. Lift the mold 300 $\mathrm{mm}$ apart in $5 \pm 2$ seconds without lateral or torsional movements. Complete all test work from the start of filling to removing the mold without interruption, in no more than $21 / 2$ minutes.

(5) After the concrete shows a decrease in the surface, measure the slump immediately by determining the vertical difference between the top of the mold and the center of the top surface of the concrete. In the event of collapse or collapse of concrete shear on one side or a part of the concrete mass. The mold is lifted and the concrete is left until there is a decrease in the top surface of the concrete. The distance between the initial surface position and the position after the settlement at the center of the upper surface of the concrete is measured and reported as the value of the concrete slump [18].

\subsection{Treatment of test objects}

After the test specimen is finished making, leave the test specimen for 24 hours, then the test specimen is opened from the mold and the test specimen is inserted into a tub containing clean water, the specimen is removed before 48 hours of testing [17]. 


\subsection{Compressive strength testing}

Compressive strength testing of the test specimens is carried out for specimens at the age of 3 days, 7 days, 14 days and 28 days. Procedure for compressive strength testing using the method [19].

\section{RESULTS AND DISCUSSION}

In this chapter describes the results that have been made from the manufacture of ironwood aggregate material, material testing, slump testing, test specimen manufacture, compressive strength testing, and discussion of the results of research.

\subsection{Material testing results}

Material test results are shown in Table 1.

Table 1. Material testing results

\begin{tabular}{ccc}
\hline Test & $\begin{array}{c}\text { Fine } \\
\text { Aggregate }\end{array}$ & $\begin{array}{c}\text { Coarse Aggregate } \\
\text { Ironwood }\end{array}$ \\
\hline $\begin{array}{c}\text { Bulk density } \\
\left(\mathrm{kg} / \mathrm{m}^{3}\right)\end{array}$ & $1.631,29$ & 621 \\
\hline Specific gravity & 2.473 & 1.012 \\
\hline Water absortption & $0,12 \%$ & $4,268 \%$ \\
\hline Fineness modulus & 3,21 & - \\
\hline Keausan/abrasi & - & 32,231 \\
\hline
\end{tabular}

\subsection{Mix design results}

The results of the mix design are shown in Table 2.

Table 2. Mix design

\begin{tabular}{cccc}
\hline $\begin{array}{c}\text { Water } \\
(\mathbf{k g})\end{array}$ & $\begin{array}{c}\text { Semen } \\
(\mathbf{k g})\end{array}$ & $\begin{array}{c}\text { Fine } \\
\text { Aggregate } \\
(\mathbf{k g})\end{array}$ & $\begin{array}{c}\text { Coarse Aggregate } \\
\text { Iroonwood }(\mathbf{k g})\end{array}$ \\
\hline 190 & 325 & 791,9 & 395,92 \\
\hline
\end{tabular}

\subsection{Slump test results}

From the slump test results as shown in Figure 3, the slump results obtained are $6 \mathrm{~cm}$.

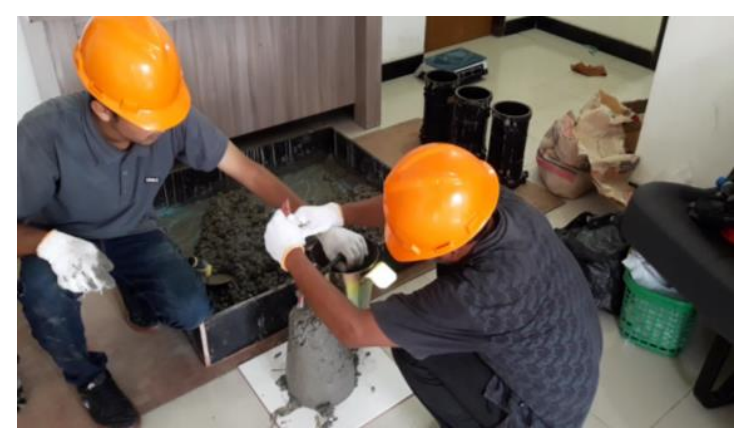

Figure 3. Test slump

\subsection{Compressive strength}

Compressive strength of specimens carried out on concrete age 3 days, 7 days, 14 days, and 28 days each concrete age tested by 3 pieces with a Digital Compression Machine, from the results of this test can be obtained concrete weight $/ \mathrm{m}^{3}$ and compressive strength concrete (MPa). The results of the concrete compressive strength test are shown in Table 3.

Table 3. Compressive strength test results

\begin{tabular}{ccc}
\hline $\begin{array}{c}\text { The test object's age } \\
\text { (days) }\end{array}$ & $\begin{array}{c}\text { Weight } \\
(\mathbf{k g})\end{array}$ & $\begin{array}{c}\text { Strong Press } \\
(\mathbf{M P a})\end{array}$ \\
\hline 3 & 1.795 & 9,75 \\
\hline 7 & 1.789 & 12,91 \\
\hline 14 & 1.776 & 16,62 \\
\hline 28 & 1.772 & 17,99 \\
\hline
\end{tabular}

\subsection{Discussion}

To get lightweight concrete, it is necessary to replace fillers such as coarse and fine aggregates whose weight and density are lower than the aggregates used for normal concrete or according to the ACI classification [16]. In this study, the replacement of coarse aggregate was replaced by making artificial coarse aggregate from ironwood. The goal is that the weight of the concrete contents can be included in the category of lightweight concrete by considering the compressive strength of lightweight concrete for the structure. The results of this study obtained several results from testing and observing specific gravity, and the weight of the ironwood aggregate content is $60 \%$ lighter than the coarse aggregate in general.

In designing mix design calculations are performed assuming all materials used for normal concrete. The normal concrete mix design is then carried out the calculation of the total replacement with a substitute material, namely coarse aggregate of ulin wood waste, all replacements taking into account the weight according to the weight required for lightweight concrete.

Deterioration test is carried out to determine the deterioration of mortar, the lower the value of deterioration, the easier the concrete work, this research is planned to decline $8 \mathrm{~cm}-18 \mathrm{~cm}$, while the results obtained by $6 \mathrm{~cm}$ this occurs because the water absorption from ironwood aggregates is higher, when compared with aggregates commonly used, to plan for slumps using ironwood aggregates, it is necessary to increase the water absorption of ironwood aggregates to get the slump values as planned.

The initial compressive strength of the mixture design is planned compressive strength of $25 \mathrm{MPa}$ at 28 days, while the results obtained in this test are $17,99 \mathrm{MPa}$, this is based on observations of test specimens due to poor bonding of ironwood aggregates with mortars. However, with a compressive strength of $17,99 \mathrm{MPa}$ with ironwood aggregates can already be included in the category of lightweight structural concrete.

\section{CONCLUSIONS}

Based on the results and discussion above, it can be concluded:

- $\quad$ Specific gravity, and lighter weight about $60 \%$ of ordinary coarse aggregate.

- The absorption of ironwood aggregate water is higher than that of coarse aggregate in general because wood absorption is higher than normal rock absorption.

- The slump test results are not in accordance with the 
target between $8 \mathrm{~cm}-18 \mathrm{~cm}$, it is influenced by the high absorption of water from ironwood aggregates. The amount of water that enters the ironwood coarse aggregate reduces the level of work of fresh concrete.

- Normal concrete weight in this mix design planning that uses SNI 0328342000 weighing $2274 \mathrm{~kg}$ per $\mathrm{m}^{3}$ to get the weight of concrete according to ACI [20] maximum weight of $1842 \mathrm{~kg} / \mathrm{m}^{3}$, for this reason, there is a need to replace both partial and complete aggregates of coarse and fine aggregates ., to get the weight and strength of the concrete that has been designed that is $25 \mathrm{MPa}$ at 28 days, the coarse aggregate is replaced by $100 \%$ by ironwood waste aggregate, the design aims to get a concrete weight below $1842 \mathrm{~kg} / \mathrm{m}^{3}$ and a concrete strength of $25 \mathrm{MPa}$ at 28 days.

Aggregate material made from ulin wood waste coated with no drop paint can be used as an alternative to artificial aggregate material to make structural lightweight concrete.

\section{ACKNOWLEDGMENT}

Thanks to Professor DR. Bambang Setiaji as Rector of Universitas Muhammadiyah Kalimantan Timur, Ghozali, Ph.D. as Affairs of Academic, Sunarso, SE., MM as Affairs of Students, and Ir. Waluyo Adi Siswanto, M.Eng., Ph.D. as Dean of Faculty Sains and Technology who have guided and support in this research.

\section{REFERENCES}

[1] Lightweight Concrete Topic. https://www.concrete.org/topicsinconcrete/topicdetail/L ightweight Concrete, accessed on 23 Aug. 2019.

[2] Types of concrete. wikipedia, 2019. https://en.wikipedia.org/wiki/Types_of_concrete, accessed on 17 Aug. 2019.

[3] Lightweight https://www.concretecentre.com/PerformanceSustainability-(1)/Special-Concrete/lightweightconcrete.aspx, accessed on 22 Aug. 2019.

[4] Subandi, Nasrulah, T., Arha, A.A,. Zulkarnain, I., Asnan, M.N. (2019). Effect of addition of rice husk charcoal on concrete compressive strength. International Journal of Engineering and Advanced Technology, 8(6): 4951-4955. https://doi.org/10.35940/ijeat.F9251.088619

[5] Subandi, Kusuma, C., Asnan, M.N., Damaiyanti, M., Yatnikasari, S. (2019). Manufacture of concrete with artificial sand from rice husk waste. International Journal of Recent Technology and Engineering, 8(3):
1670-1673.

https://www.doi.org/10.35940/ijrte.C4438.098319

[6] Venkatesh, C., Chand, M., Nerella, R. (2019). A state of the art on red mud as a substitutional cementitious material. Annales de Chimie - Science des Matériaux, 43(2): 99-106. https://doi.org/10.18280/acsm.430206

[7] Nurulla, S., Mustafa, S., Reddy, Y. (2019). Investigation on mechanical properties of lightweight concrete partially replacing sawdust to fine aggregate. Annales de Chimie - Science des Matériaux, 43(2): 125128. https://doi.org/10.18280/acsm.430210

[8] Subandi, Arha, A.A., Kusuma,C., Asnan, M.N. (2019). Utilization of ironwood waste and husk charcoal to produce lightweight concrete. International Journal of Civil Engineering, 6(7): 17-22. https://doi.org/10.14445/23488352/IJCE-V6I7P104

[9] Avian Brands | No Drop. https://avianbrands.com/product/detail/no-drop, accessed on 17 Aug. 2019.

[10] Astm, S.N.I. (2012). Metode uji untuk analisis saringan agregat halus dan agregat kasar (ASTM C 136-06, IDT).

[11] Pengujian, M., Lempung, G., Pecah, M., Agregat, D. (1996). Metode pengujian gumpalan lempung dan butirbutir mudah pecah dalam agregat. pp. 1-6.

[12] SNI 03-1970-1990. (1990). Metode Pengujian Berat Jenis dan penyerapan air agregat halus. Bandung: Badan Standardisasi Indonesia, pp. 1-17.

[13] SNI 03-4804-1998. (1998). Metode Pengujian Bobot Isi dan Rongga Udara dalam Agregat. Balitbang PU, pp. 16.

[14] Pusat Penelitian dan Pengembangan Transportasi Jalan. (1996). Metode Pengujian Jumlah Bahan Dalam Agregat. SNI 03-4142-1996, 200(200): 1-6.

[15] Sni-astm-c136-2012, "sni-astm-c136-2012.pdf." 2012.

[16] SNI 03-2834-2000. (2000). Standar Nasional Indonesia Tata cara pembuatan rencana campuran beton normal. Sni 03-2834-2000.

[17] SNI 03-4810-1998. (1998). Metode Pembuatan dan Perawatan Benda Uji di Lapangan, pp. 1-8.

[18] SNI-1972-2008. (2008). Cara Uji Slump Beton. Badan Standar Nasional Indonesia.

[19] ASTM-C39/C39M-18. ASTM C39 / C39M - 18 Standard Test Method for Compressive Strength of Cylindrical Concrete Specimens, 2018. https://www.astm.org/Standards/C39, accessed on 30 Jul. 2019.

[20] A. Committee. ACI 213R-03. (2003). Guide for Structural Lightweight-Aggregate Concrete, ACI COMMITTEE REPORT, pp. 1-4. 